\title{
Tumor Necrosis Factor-alpha Gene Expression in PBMCs of Iranian Azeri Turkish Patients with Premature Coronary Artery Disease (Age $\leq 50$ Years)
}

Mahssa HASSAN-NEJHAD ${ }^{a}$, Morteza BAGHERI ${ }^{b}$, Kamal KHADEM-VATANIc, Mir Hossein SEYED MOHAMMAD ZAD ${ }^{c}$, Isa ABDI RAD ${ }^{b}$, Behzad RAHIMIc, Ali ROSTAMZADEH ${ }^{c}$, Amir RAHIMLOU ${ }^{c}$

aslamic Azad University of Bonab Complex, Bonab, Iran

${ }^{b}$ Cellular and Molecular Research Center, Urmia University of Medical Sciences, Urmia, Iran

'Seyyed-al Shohada University Hospital, Urmia University of Medical Sciences, Urmia, Iran

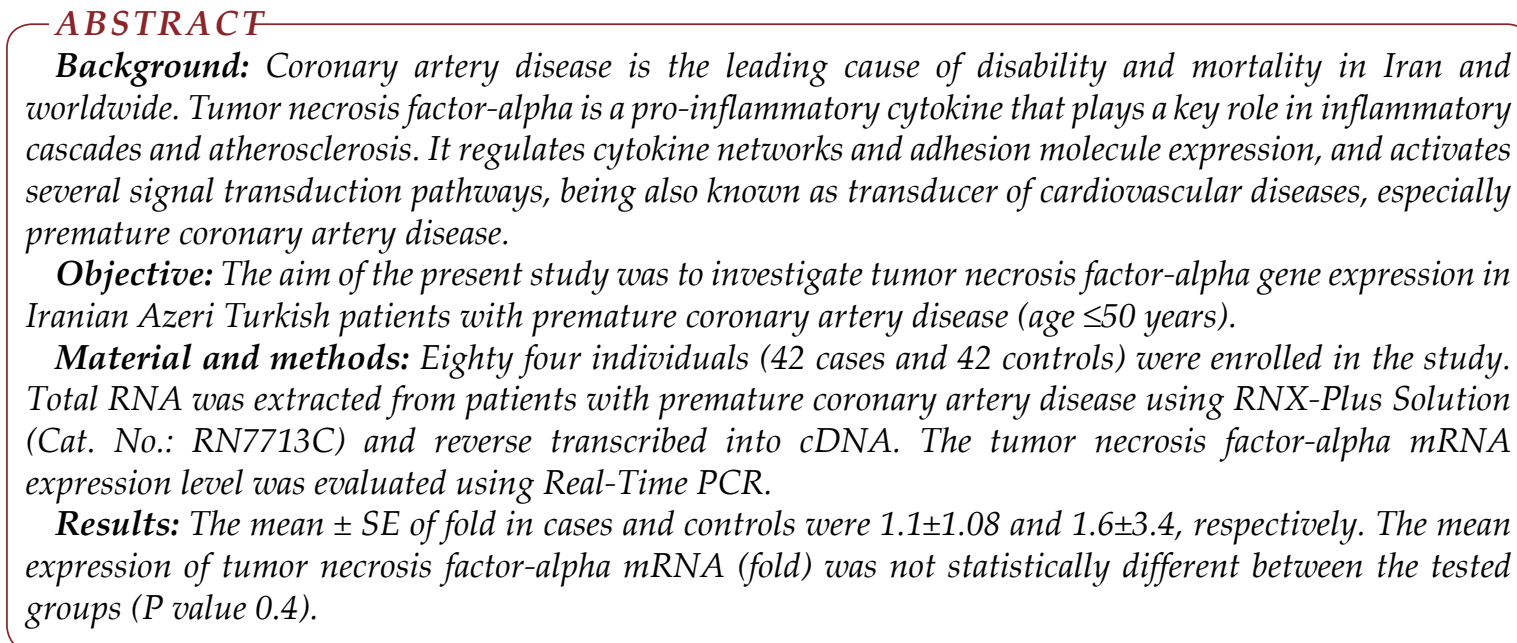

\footnotetext{
Address for correspondence:

Morteza Bagheri, PhD, Assistant Professor

Cellular and Molecular Research Center, Urmia University of Medical Sciences, Urmia, Iran

P.O. Box: 5756115111

Tel: +98-443-2770969, Fax: +98-443-2234125

Email: mortazabagheri@yahoo.com
}

Article received on the $14^{\text {th }}$ of November and accepted for publication on the $22^{\text {nd }}$ of December 2017. 
Outcomes: Our outcome failed to find evidence for any association between tumor necrosis factor-alpha $m R N A$ expression and premature coronary artery disease. Large scale, more detailed studies are further needed to prove our results and to propose other mechanisms in the pathophysiology of premature coronary artery disease.

Keywords: TNF- $\alpha$, gene expression, premature coronary artery disease.

\section{INTRODUCTION}

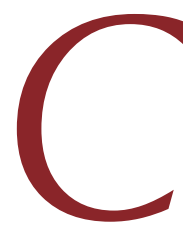

oronary artery disease (CAD) is the leading cause of disability and mortality in Iran and worldwide (1). The average age of onset of premature coronary artery disease (PCAD) is about $36.23 \pm 15.26$ among Iranians (2). Several studies analysed the role of traditional risk factors, such as family history of PCAD, male gender, arterial hypertension, hyperlipidemia, cigarette smoking, obesity (BMI $>30 \mathrm{~kg} / \mathrm{m}^{2}$ ) and diabetes mellitus, in PCAD (3). The results of several genome-wide association studies pointed to a complex genetic basis of PCAD (4-6). Atherosclerosis is the primary cause of PCAD (7). Cytokines and cytokine genes may play a central role in the pathogenesis of atherosclerosis. Tumor necrosis factor-alpha (TNF- $\alpha$ ) is defined as a critical risk factor for pathogenesis and progression of atherosclerosis (8). Cytokine gene polymorphisms may influence the risk of PCAD (9). The pathogenesis of PCAD must be in association with a large number of biological networks and genes (10). TNF- $\alpha$ regulates cytokine networks and adhesion molecule expression, and activates several signal transduction pathways, being also known as transducer of cardiovascular diseases, exclusively PCAD $(11,12)$. Several studies evaluated the role of TNF- $\alpha$ and TNF- $\alpha$ receptor polymorphisms in CAD and ischemic heart disease (13-16). Sbarsi et al implied that TNF-308 A allele is a predisposing factor and significantly increases the risk of CAD (17). Enayati et al studied a group of cases aged $>50$ years and failed to find a significant difference between patients with and without CAD regarding TNF- $\alpha$ gene expression (18). Atherosclerosis is identified as an age-associated inflammatory disease (19). Bruunsgaard et al indicated that there was a relation between high levels of TNF- $\alpha$ in the blood and atherosclerosis in a cohort of 81-year-old subjects (20). Coronary artery disease occurs in all age groups, but the aim of this study was to inves- tigate TNF- $\alpha$ gene expression in peripheral blood mononuclear cells (PBMCs) of Iranian Azeri Turkish patients with PCAD at younger age ( $\leq 50$ years).

\section{MATERIALS AND METHODS}

The Present study was approved by the Ethical Committee of Urmia University of Medical Sciences (Ir.umsu.rec.1394.138). Eighty four individuals (42 cases and 42 controls) from the same geographical region and ethnicity were enrolled in the study, which was carried out at Urmia University of Medical Sciences (Urmia, Iran). Strict criteria were used for selection of patients who had a minimum of one angiographically documented coronary artery with $50 \%$ stenosis (21). The diagnosis of PCAD was established by electrocardiography, coronary angiography and echocardiography (22). None of our contributors were clinically diagnosed with Familial Mediterranean Fever (FMF), familial hypercholesterolemia, arteriovenous graft, congenital defects of the heart valves and other related systemic diseases. Each person was informed about the contents and aims of this study. All subjects were evaluated by an expert cardiologists based on the accepted criteria. Blood samples (2-3 mL) were obtained in EDTA-containing tubes for RNA isolation. RNA extraction was started within 24 hours after sample collection using RNX plus (Cat. No.: RN7713C) (Cinnagen, Iran). RNA samples were preserved at -80oC until cDNA synthesis was performed. The purity of RNA extracts was tested via measuring absorption at $260 \mathrm{~nm}$ and $280 \mathrm{~nm}$ in a biophotometer (Eppendorf AG, Germany), and the $260 \mathrm{~A} / 280 \mathrm{~A}$ ratio higher than 1.8 was considered as acceptable. The Thermo Scientific RevertAid First Strand cDNA Synthesis Kit was used for cDNA synthesis from $2 \mu \mathrm{L}$ of each sample. Thermo scientific SYBER Green/ROX qPCR Master Mix (2X) and $2 \mu \mathrm{L}$ template cDNA were used for Real Time PCR in the $\mathrm{iQ}^{\text {TM }} 5$ Multicolor Real-Time PCR Detection System 
(BIO-RAD). In our samples, TNF- $\alpha$ mRNA expression was evaluated using two sets of primers including $\mathrm{F}$ : $5^{\prime}$-cccaggcagtcagatcatcttc- $3^{\prime}$ and R: $5^{\prime}$-agctgcccctcagcttga-3' for TNF- $\alpha$ (Amplicon size: 85 bp), and F: 5'-cctggcgtcgtgattagtgat-3' and R: 5'-agacgttcagtcctgtccataa-3' for hypoxanthine-guanine phosphoribosyltransferase (HPRT) (Amplicon size: $131 \mathrm{bp)} \mathrm{(18).} \mathrm{The} \mathrm{PCR} \mathrm{program}$ included: $95^{\circ} \mathrm{C}$ for five minutes; 40 cycles: $95^{\circ} \mathrm{C}$ for $30 \mathrm{~s}$ and $68^{\circ} \mathrm{C}$ for $20 \mathrm{~s}$. All analyses were carried out in duplicate reactions. $2^{-\Delta \Delta C T}$ method was performed for determining the relative gene expression between tested groups (23). Data are reported as the fold \pm SE normalized to HPRT as endogenous reference.

\section{STATISTICAL ANALYSIS}

A II data were reported as means \pm standard deviation (mean $\pm \mathrm{SD}$ ) or mean \pm standard error of mean (SEM). Mann-Whitney $U$ tests were performed for data analysis by Statistical Package for Social Sciences (SPSS) 22 software. Relative amounts of mRNA expressions (fold) were compared between tested groups via independent sample t-test. The statistically significant level was set at $P$ value $<0.05$.

\section{RESULTS}

linical findings among patients with PCAD and controls are summarized in Table 1 and Figure 1. We studied 42 patients including 36 $(85.7 \%)$ males and six (14.3\%) females, as well as 42 controls including 15 (35.7\%) males and 27 (64.3\%) females. Cases and controls had an average age of $45.25 \pm 5.28$ and $44.95 \pm 4.01$, respectively, and a mean \pm SE of fold of $1.1 \pm 1.08$ and

\begin{tabular}{|c|c|c|c|c|}
\hline Parameters & $\begin{array}{l}\text { Patients with } \\
\text { PCAD F (\%) }\end{array}$ & $\begin{array}{c}\text { Controls } \\
\text { F (\%) }\end{array}$ & $\begin{array}{c}\text { OR } \\
(95 \% \mathrm{CI})\end{array}$ & $\begin{array}{c}P \\
\text { value }\end{array}$ \\
\hline $\begin{array}{l}\text { Diabetic } \\
\text { nephropathy }\end{array}$ & $5(11.90)$ & $10(23.81)$ & $0.43(0.13-1.4)$ & 0.15 \\
\hline Blood pressure & $6(14.28)$ & $14(33.33)$ & $0.33(0.11-0.98)$ & 0.04 \\
\hline Dyslipidemia & $8(19.04)$ & 11 (26.19) & $0.66(0.24-1.90)$ & 0.43 \\
\hline $\begin{array}{l}\text { Positive family } \\
\text { history for } \\
\text { PCAD }\end{array}$ & $13(30.95)$ & $12(28.57)$ & $1.12(0.44-2.86)$ & 0.81 \\
\hline $\begin{array}{l}\text { Positive history } \\
\text { of cigarette } \\
\text { smoking }\end{array}$ & $20(47.61)$ & $9(21.42)$ & $3.33(1.28-8.65)$ & 0.01 \\
\hline
\end{tabular}

TAB LE 1. Clinical findings among patients with PCAD and controls included in the study

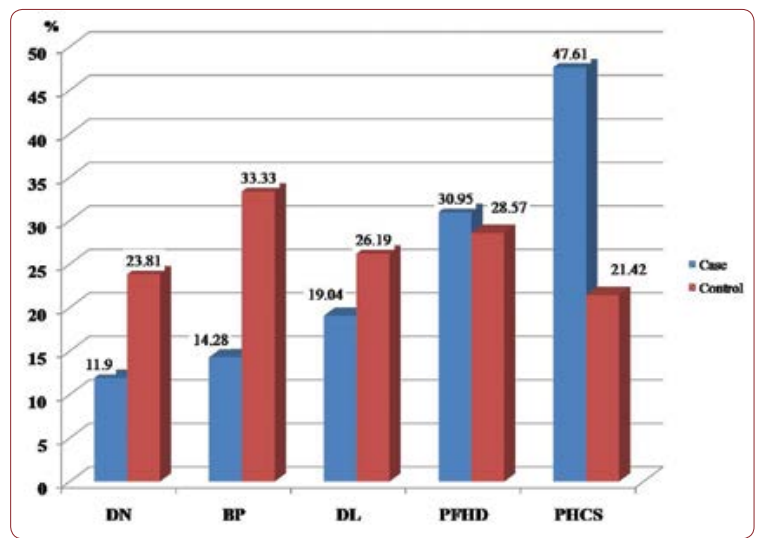

FIGURE 1. Clinical findings among patients and controls;

$\mathrm{DN}=$ diabetic nephropathy; $\mathrm{BP}=$ blood pressure; $\mathrm{DL}=$ dyslipidemia; PFHD=positive family history for PCAD disease; PHCS=positive history of cigarette smoking

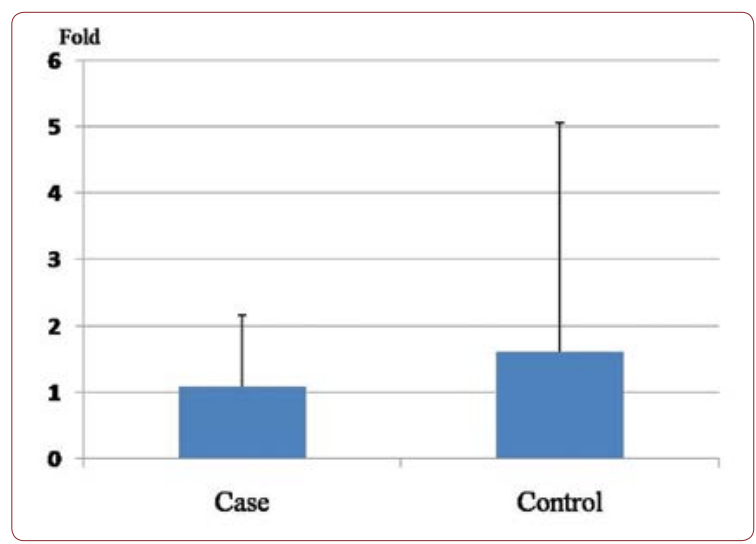

FIGURE 2. Mean expression of TNF- $\alpha$ mRNA (fold) in cases and controls. The fold of relative mRNA expression was $1.1 \pm 1.08$ in cases and $1.6 \pm 3.4$ in controls for TNF- $\alpha$. The study showed that there were no significant differences among tested groups $(\mathrm{P}$ value 0.4$)$. Data are expressed as means \pm SEM

$1.6 \pm 3.4$, respectively. The mean expression of TNF- $\alpha$ mRNA (fold) was not statistically different in the tested groups (P value 0.4) (Figure 2). Traditional risk factor of cigarette smoking was present more frequently among our cases (47.61\%). Figure 3 shows amplification plot for quantitative analysis of TNF- $\alpha$ gene expression using Real Time PCR analysis (a) and an image of a gel post electrophoresis of TNF- $\alpha$ (85 bp) and hypoxanthine-guanine phosphoribosyltransferase (HPRT) (131 bp) (b).

\section{DISCUSSIONS}

CAD-susceptible cytokine alleles may influence the pathophysiology of diseases via up- 


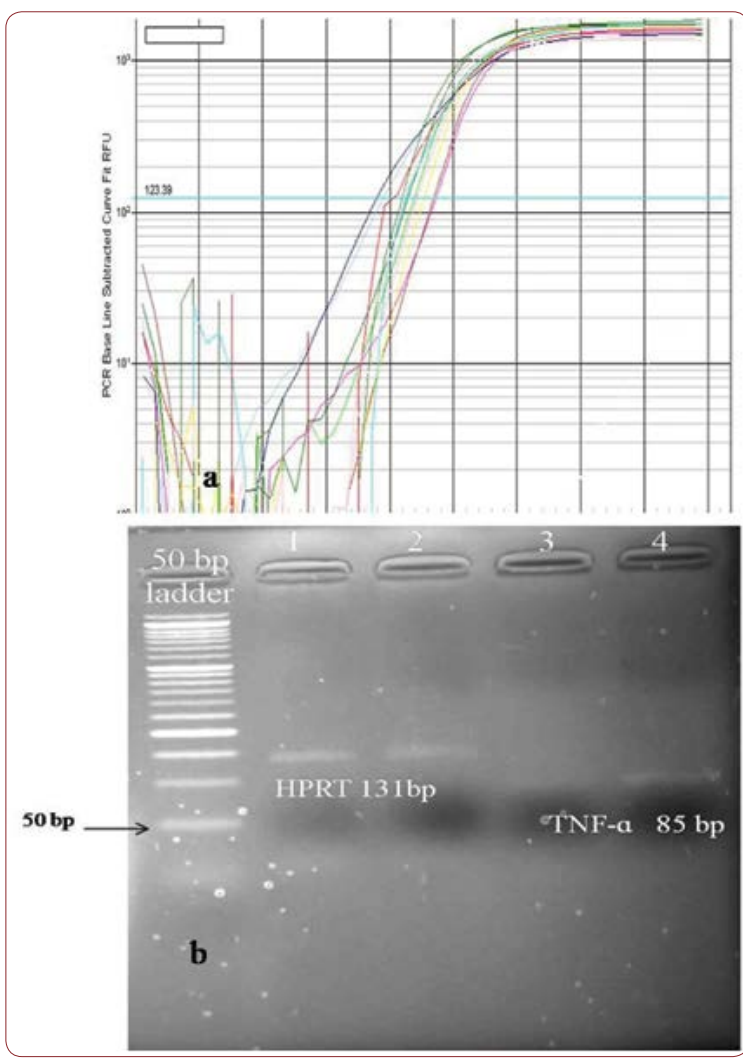

FIGURE 3. a) Amplification plot for quantitative analysis of TNF- $\alpha$ gene expression, using real time PCR analysis. b) Image of a gel post electrophoresis of TNF- $\alpha$ and HPRT regarding Real Time PCR analysis

regulation of inflammatory gene(s) expression $(24,25)$. TNF- $\alpha$ is involved in the secretion and production of other cytokines, such as chemokines, that have a role in leukocyte trafficking to the site of inflammation (25). TNF- $\alpha$ acts in concert with other genes, such as IL-6 (25) or IL-1, transforming growth factor-beta in heart failure (26). There are large bodies of investigations that indicate an association between stress and heart disease (24). TNF- $\alpha$ is defined as an important indicator of stress (24). Several studies evaluated the level of TNF- $\alpha$ in heart diseases such as CAD and heart failure (27-33). TNF- $\alpha$ has the potential to recognize the grade of atherosclerosis, and high levels of soluble tumor necrosis factor receptors (sTNFRs) in serum play an active inflammatory role in health and disease $(33,34)$. It has been indicated that the value of TNF/TNFR ratios as an important predictor may influence the pathophysiology of diseases (34). In addition to a central role of TNF- $\alpha$ in host defense, inflammation and hematopoiesis, TNFR subtypes have been also shown to have an important role in human diseases $(34,35)$.

To the best of our knowledge, the present study is the first investigation evaluating the mean expression of TNF- $\alpha$ mRNA (fold) in patients with PCAD (age $\leq 50$ years). We failed to find significant differences between cases and controls regarding the mean expression of TNF- $\alpha$ mRNA (fold). Our finding is in agreement with that reported by Enayati et al (18). Cardiovascular disorders may be influenced by TNF- $\alpha$ and TNF/TNFR ratios (34). The CAD comprises approximately one third of cardiovascular disorders (36). It has been demonstrated that TNFR2 signaling pathway is involved in the cardiovascular system (37). Additional studies and analysis are required to resolve this debate.

Our study had a low sample size, and cases and controls were not matched by gender, stress and economic status. Another limitation of this investigation was that the cross-sectional design did not allow us to evaluate the origin-effect factors. Patients with PCAD may have several risk factors such as psychosocial factors, fruit and vegetable consumption, stress and physical activity (38). Molecular analysis of other genes and their pathophysiological effects on the pathogenesis of PCAD, such as TNFRs, needs to be carried out. Large scale, more detailed studies are further necessary to confirm these results.

\section{CONCLUSION}

$\mathrm{O}$ ur outcome failed to find evidence for association between TNF- $\alpha$ mRNA expression and PCAD. Large scale, more detailed studies are needed in the future to suggest new mechanisms..

Acknowledgments: We are grateful to participants for providing the samples as well as to hospital medical staff for collecting the samples.

Conflicts of interest: none declared.

Financial statement: none declared. 


\section{References}

1. Sadeghi R, Adnani N, Erfanifar A, et al. Premature coronary heart disease and traditional risk factors-can we do better? Int Cardiovasc Res J 2013;2:46-50.

2. Hatmi ZN, Tahvildari S, Gafarzadehmotlag A, Sabourikashani A. Prevalence of coronary artery disease risk factors in Iran: a population based survey. BMC CardiovascDisord 2007;7:32.

3. Mohammad AM, Jehangeer HI, Shaikhow SK. Prevalence and risk factors of premature coronary artery disease in patients undergoing coronary angiography in Kurdistan, Iraq.

BMC CardiovascDisord 2015;15:155.

4. Mcpherson R, Tybjaerg-Hansen A. Genetics of Coronary Artery Disease. Circ Res 2016;4:564-578.

5. Pranavchand R, Reddy BM. Current status of understanding of the genetic etiology of coronary heart disease. J Postgrad Med 2013;1:30-41.

6. Roberts R. Genetics of coronary artery disease: an update. Methodist Debakey Cardiovasc J 2014;1:7-12.

7. Weber C, Noels H. Atherosclerosis: current pathogenesis and therapeutic options. Nat Med 2011;11:1410-1422.

8. Mckellar GE, Mccarey DW, Sattar N, Mcinnes IB. Role for TNF in atherosclerosis? Lessons from autoimmune disease. Nat Rev Cardiol 2009;6:410-417.

9. Auer J, Weber T, Berent R, et al. Genetic polymorphisms in cytokine and adhesion molecule genes in coronary artery disease. Am J Pharmacogenomics 2003;5:317-328.

10. Rezaee-Zavareh MS, Tohidi M, Sabouri A, et al. Infectious and coronary artery disease. ARYA Atheroscler 2016;1:41-49.

11. Hansson GK. Inflammation, atherosclerosis, and coronary artery disease. N Engl J Med 2005;352:1685-1695.

12. Bellisarii FL, Gallina S, De Caterina R. Tumor necrosis factor-alpha and cardiovascular diseases. Ital Heart J 2001;6:408-417.

13. Cheng $Y$, An B, Jiang M, et al. Association of tumor necrosis factor-alpha polymorphisms and risk of coronary artery disease in patients with non-alcoholic fatty liver disease. Hepat Mon 2015;3:e26818.

14. Pereira TV, Rudnicki M, Franco RF, et al. Effect of the G-308A polymorphism of the tumor necrosis factor alpha gene on the risk of ischemic heart disease and ischemic stroke: a meta-analysis.
Am Heart J 2007;5:821-830.

15. Zhang HF, Xie SL, Wang JF, et al. Tumor necrosis factor-alpha G-308A gene polymorphism and coronary heart disease susceptibility: an updated meta-analysis. Thromb Res 2011;5:400-405.

16. Zhang $P, \mathbf{W u} X, \mathrm{Li} \mathrm{G}$, et al. Tumor necrosis factor-alpha gene polymorphisms and susceptibility to ischemic heart disease: A systematic review and meta-analysis. Medicine (Baltimore) 2017;14:e6569.

17. Sbarsi I, Falcone $C$, Boiocchi $C$, et al. Inflammation and atherosclerosis: the role of TNF and TNF receptors polymorphisms in coronary artery disease. Int I Immunopathol Pharmacol 2007;1:145-154.

18. Enayati $S$, Seifirad $S$, Amiri $P$, et al. Interleukin-1 beta, interferon-gamma, and tumor necrosis factor-alpha gene expression in peripheral blood mononuclear cells of patients with coronary artery disease. ARYA Atheroscler 2015;5:267-274.

19. Ross R. Atherosclerosis - an inflammatory disease. N Engl J Med 1999;340:115-126.

20. Bruunsgaard H, Skinhøj P, Pedersen AN, et al. Ageing, tumour necrosis factor-alpha (TNF-alpha) and atherosclerosis. Clin Exp Immunol 2000;2:255-260.

21. Cassar A, Holmes DR Jr, Rihal CS, Gersh BJ. Chronic coronary artery disease: diagnosis and management. Mayo Clin Proc 2009;12:1130-1146.

22. Banerjee A, Newman DR, Van Den Bruel A, Heneghan C. Diagnostic accuracy of exercise stress testing for coronary artery disease: a systematic review and meta-analysis of prospective studies. Int J Clin Pract 2012;5:477-492.

23. Livak KJ, Schmittgen TD. Analysis of relative gene expression data using real-time quantitative PCR and the 2(-Delta DeltaC(T)) Method. Methods 2001;4:402-408.

24. Dimsdale JE. Psychological stress and cardiovascular disease. J Am Coll Cardiol 2008;13:1237-1246.

25. Yudkin JS, Kumari M, Humphries SE, Mohamed-Ali V. Inflammation, obesity, stress and coronary heart disease: is interleukin-6 the link? Atherosclerosis 2000;2:209-214.

26. Feldman AM, Combes A, Wagner D, et al. The role of tumor necrosis factor in the pathophysiology of heart failure. J Am Coll Cardiol 2000;3:537-544.
27. Deswal A, Petersen NJ, Feldman AM, et al. Cytokines and cytokine receptors in advanced heart failure: an analysis of the cytokine database from the vesnarinone trial (VEST). Circulation 2001;16:2055-2059.

28. Levine B, Kalman J, Mayer L, et al. Elevated circulating levels of tumor necrosis factor in severe chronic heart failure. N Engl J Med 1990;4:236-241.

29. Petersen JW, Felker GM. Inflammatory biomarkers in heart failure. Congest Heart Fail 2006;6:324-328.

30. Zhang C, Xu X, Potter BJ, et al. TNF-alpha contributes to endothelial dysfunction in ischemia/reperfusion injury. Arterioscler Thromb Vasc Biol 2006;3:475-480.

31. Latini R, Bianchi M, Correale E, et al. Cytokines in acute myocardial infarction: selective increase in circulating tumor necrosis factor, its soluble receptor, and interleukin-1 receptor antagonist. J Cardiovasc Pharmacol 1994;1:1-6.

32. Khan DA, Ansari WM, Khan FA. Pro/anti-inflammatory cytokines in the pathogenesis of premature coronary artery disease. J Interferon Cytokine Res 2011;7:561-567.

33. Gotsman I, Stabholz A, Planer D, et al. Serum cytokine tumor necrosis factor-alpha and interleukin-6 associated with the severity of coronary artery disease: indicators of an active inflammatory burden? Isr Med Assoc J 2008;7:494-498.

34. Mcdermott MF. TNF and TNFR biology in health and disease. Cell Mol Biol (Noisy-le-grand) 2001;4:619-635.

35. Asano Y, Shibata S, Kobayashi S, et al. Effect of interleukin 10 on the hematopoietic progenitor cells from patients with aplastic anemia. Stem Cells 1999;3:147-151.

36. Wilson PW, D'agostino RB, Levy D, et al. Prediction of coronary heart disease using risk factor categories. Circulation 1998;18:1837-1847.

37. Luo Y, Xu Z, Wan T, et al. Endothelialspecific transgenesis of TNFR2 promotes adaptive arteriogenesis and angiogenesis. Arterioscler Thromb Vasc Biol 2010;7:1307-1314.

38. Sapranaviciute-Zabazlajeva $L$, Luksiene D, Virviciute D, et al. Link between healthy lifestyle and psychological well-being in Lithuanian adults aged 45-72: a cross-sectional study. BMJ Open 2017;4:e014240. 